\title{
Latitudinal distribution and mitochondrial DNA (COI) variability of Stereotydeus spp. (Acari: Prostigmata) in Victoria Land and the central Transantarctic Mountains
}

\author{
NICHOLAS J. DEMETRAS ${ }^{1}$, IAN D. HOGG ${ }^{\mathbf{1}}$, JONATHAN C. BANKS ${ }^{\mathbf{1}}$ and BYRON J. ADAMS ${ }^{\mathbf{2}}$ \\ ${ }^{1}$ Department of Biological Sciences, University of Waikato, Private Bag 3105, Hamilton, New Zealand \\ ${ }^{2}$ Microbiology \& Molecular Biology Department, Evolutionary Ecology Laboratories, Brigham Young University, 775 WIDB, \\ Provo, UT 84602-5253, USA \\ nd31@waikato.ac.nz
}

\begin{abstract}
We examined mitochondrial DNA (COI) variability and distribution of Stereotydeus spp. in Victoria Land and the Transantarctic Mountains, and constructed Neighbour Joining (NJ) and Maximum Likelihood (ML) phylogenetic trees using all publicly available COI sequences for the three Stereotydeus species present (S. belli, S. mollis and $S$. shoupi). We also included new COI sequences from Miers, Marshall and Garwood valleys in southern Victoria Land $\left(78^{\circ} \mathrm{S}\right)$, as well as from the Darwin $\left(79^{\circ} \mathrm{S}\right)$ and Beardmore Glacier $\left(83^{\circ} \mathrm{S}\right)$ regions. Both $\mathrm{NJ}$ and $\mathrm{ML}$ methods produced trees which were similar in topology differing only in the placement of the single available $S$. belli sequence from Cape Hallett $\left(72^{\circ} \mathrm{S}\right)$ and a $S$. mollis haplotype from Miers Valley. Pairwise sequence divergences among species ranged from 9.5-18.1\%. NJ and ML grouped S. shoupi from the Beardmore Glacier region as sister to those from the Darwin with pairwise divergences of $8 \%$. These individuals formed a monophyletic clade with high bootstrap support basal to $S$. mollis and $S$. belli. Based on these new data, we suggest that the distributional range of $S$. shoupi extends northward to Darwin Glacier and that a barrier to dispersal for Stereotydeus, and possibly other arthropods, exists immediately to the north of this area.
\end{abstract}

Received 7 April 2010, accepted 26 July 2010

Key words: Antarctica, Arthropoda, dispersal, environmental gradients, mites, Ross Dependency

\section{Introduction}

The free-living soil mite genus Stereotydeus Berlese, 1901 (Acari: Prostigmata) comprises a circumpolar group with a broad southern hemisphere distribution of ancient Gondwanan origin (Womersley \& Strandtmann 1963, Fittkau et al. 1969, Spain \& Luxton 1971, Olivier 2006). Within the continental and maritime Antarctic, Stereotydeus is represented by eight species, seven of which are endemic (Marshall \& Pugh 1996). Of the eight species, three (S. belli, S. mollis, S. shoupi) are known from Victoria Land and the central Transantarctic Mountains (Womersley \& Strandtmann 1963, Strandtmann 1967), where they exist in mostly non-overlapping succession from north to south (Fig. 1).

Stereotydeus belli Trouessart 1902 is common in northern Victoria Land where Caruso \& Bargagli (2007) report that in, and near, Springtail Valley (c. $74^{\circ} 42^{\prime}$ S), the southern limit of S. belli overlaps with the northern limit of Stereotydeus mollis Womersley \& Strandtmann 1963. South of the Drygalski Ice Tongue $\left(75^{\circ} 24^{\prime} \mathrm{S}\right), S$. mollis becomes the dominant acarine inhabiting ice-free areas of the continent and the offshore islands in the McMurdo Sound region, including Ross and Beaufort islands (Womersley \& Strandtmann 1963). The southern distributional limit of $S$. mollis is somewhat uncertain, due mostly to limited sampling. However, the species has been reported to occur as far south as Minna Bluff (c. 78 $40^{\prime} \mathrm{S}$ ) (Gressitt et al. 1963, Strandtmann 1967). Immediately to the south of Minna Bluff is an extensively ice-covered region (hatched area Fig. 1), and information on the occurrence of mites beyond this area is limited. Spain (1971) carried out the first comprehensive arthropod surveys of the ice-free regions in proximity to Darwin Glacier $\left(c .80^{\circ} \mathrm{S}\right)$ and reported a complete absence of both Collembola and Acari. However, during the summers of 2004 and 2007, individuals of Stereotydeus were collected from ice-free areas adjacent to the Darwin Glacier $\left(79^{\circ} 49^{\prime} \mathrm{S}, 159^{\circ} 26^{\prime} \mathrm{W}\right)$.

South of the Darwin glacier, Stereotydeus shoupi Strandtmann 1967 is known from the ice free areas of the Queen Maud Mountains near the Beardmore and Shackleton glaciers $\left(\right.$ c. $83^{\circ}-85^{\circ}$ S) (Strandtmann 1967, Stevens \& Hogg 2006). Owing to the limited field surveys of invertebrates south of Minna Bluff, the distributional limits and/or any phylogeographic breaks for $S$. mollis and S. shoupi were previously unknown.

Throughout their respective geographic ranges, S. belli, S. mollis, and S. shoupi share morphological characters that overlap (Strandtmann 1967). Furthermore, several developmental stages with variable morphological characters may be present at a particular site or at differing sites due to environmental conditions which can present a challenge when 


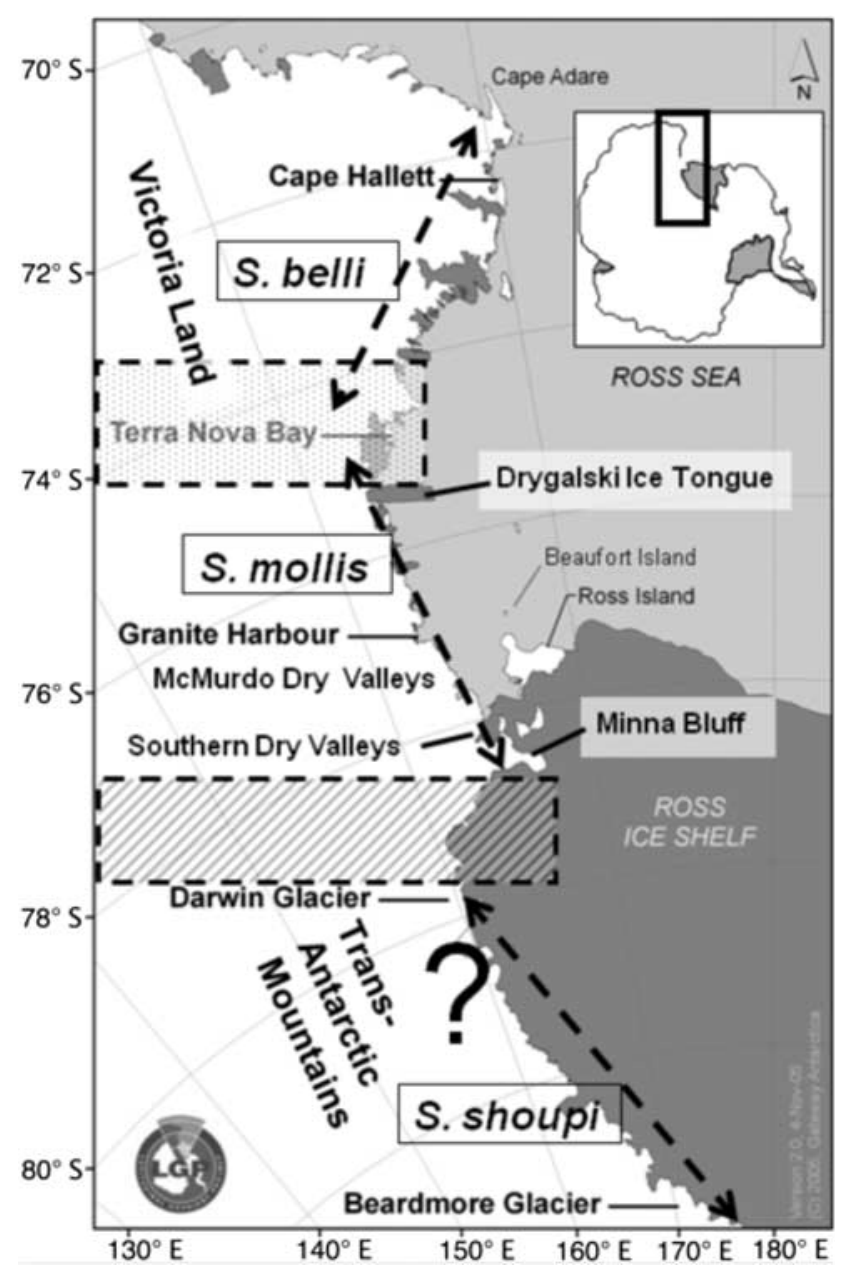

Fig. 1. Location of the Victoria Land Transantarctic latitudinal gradient (inset) showing the known, approximate distributions for three species of Stereotydeus ( $S$. belli, S. mollis, S. shoupi). Place names are referred to in the text. McMurdo Dry Valleys include Victoria, Wright and Taylor valleys; Southern Dry Valleys include Garwood, Marshall and Miers valleys. The stippled area indicates an area of overlap in the distributions of $S$. belli and $S$. mollis. The hatched area indicates an ice-covered area that occurs between the ranges of $S$. mollis and $S$. shoupi. The question mark ("?") indicates an area where limited information is currently available on the distribution of S. shoupi.

using morphological characters to distinguish between species (Gressitt et al. 1964). For example, one of the few defining characters between $S$. mollis and $S$. shoupi is the number of microscopic setae present on the genital cover, six for $S$. mollis and seven for $S$. shoupi. However, the number of setae on each genital cover is different during each of the five developmental stages of $S$. mollis (Strandtmann 1967, Pittard 1971). Although no comparable studies for S. shoupi or $S$. belli have been conducted to date, it is reasonable to assume that similar characters are also likely to vary for these species, thus complicating taxonomic assignments, particularly for immature individuals.
Table I. Stereotydeus mollis haplotype codes used in this manuscript with cross reference to previous studies and GenBank accession numbers.

\begin{tabular}{|c|c|c|c|c|}
\hline $\begin{array}{l}\text { Haplotype } \\
\text { code }\end{array}$ & Location & $\begin{array}{c}\text { Stevens \& } \\
\text { Hogg (2006) }\end{array}$ & $\begin{array}{l}\text { McGaughran } \\
\text { et al. (2008) }\end{array}$ & $\begin{array}{l}\text { GenBank } \\
\text { accession no }\end{array}$ \\
\hline Sm1 & DV & A & & DQ305386 \\
\hline $\operatorname{Sm} 2$ & DV & B & & DQ305389 \\
\hline Sm3 & DV, & D & & DQ305391 \\
\hline Sm4 & $\mathrm{DV}, \mathrm{SV}$, & E & & DQ305398 \\
\hline Sm5 & DV, SV & F & & DQ305392 \\
\hline Sm6 & $\mathrm{DV}, \mathrm{SV}, \mathrm{RI}$ & G & & DQ305396 \\
\hline $\operatorname{Sm} 7$ & $\mathrm{DV}, \mathrm{SV}, \mathrm{RI}$ & $\mathrm{H}$ & & DQ305368 \\
\hline Sm8 & DV, SV, & I & & DQ305387 \\
\hline Sm9 & DV, SV, RI & $\mathrm{J}$ & & DQ305397 \\
\hline Sm10 & $\mathrm{DV}, \mathrm{SV}$ & K & & DQ305385 \\
\hline Sm11 & DV, RI & $\mathrm{L}$ & & DQ305390 \\
\hline Sm12 & GH & M & & DQ305394 \\
\hline $\operatorname{Sm} 13$ & DV & $\mathrm{N}$ & & DQ305393 \\
\hline Sm14 & SV, BI & $\mathrm{O}$ & & DQ309572 \\
\hline Sm15 & DV, BI & $\mathrm{P}$ & & DQ305395 \\
\hline Sm16 & DV & Q & & DQ309573 \\
\hline Sm17 & BI & $\mathrm{R}$ & & DQ309574 \\
\hline Sm18 & DV & & S1 & DQ305361 \\
\hline Sm19 & DV & & S2 & DQ305362 \\
\hline $\operatorname{Sm} 20$ & DV & & S3 & DQ305363 \\
\hline $\operatorname{Sm} 21$ & DV & & S4 & DQ305364 \\
\hline $\operatorname{Sm} 22$ & DV & & S5 & DQ305365 \\
\hline $\operatorname{Sm} 23$ & DV & & S6 & DQ305367 \\
\hline $\operatorname{Sm} 24$ & DV, SV & & S7 & DQ305369 \\
\hline $\operatorname{Sm} 25$ & DV, RI & & S8 & DQ305370 \\
\hline $\operatorname{Sm} 26$ & DV & & S9 & DQ305371 \\
\hline $\mathrm{Sm} 27$ & DV & & S10 & DQ305372 \\
\hline $\operatorname{Sm} 28$ & DV & & S11 & DQ305373 \\
\hline Sm29 & DV & & S12 & DQ305374 \\
\hline $\mathrm{Sm} 30$ & DV & & S13 & DQ305375 \\
\hline Sm31 & DV & & S14 & DQ305376 \\
\hline Sm32 & DV & & S15 & DQ305377 \\
\hline Sm33 & DV & & S16 & DQ305378 \\
\hline $\mathrm{Sm} 34$ & DV & & S17 & DQ305379 \\
\hline Sm35 & DV & & S18 & DQ305380 \\
\hline Sm36 & DV & & S19 & DQ305381 \\
\hline Sm37 & DV & & S20 & DQ305382 \\
\hline $\operatorname{Sm} 38$ & DV & & S21 & DQ305383 \\
\hline Sm39 & DV & & S22 & DQ305384 \\
\hline $\operatorname{Sm} 40$ & SV & & & HM537082 \\
\hline Sm41 & SV & & & HM537083 \\
\hline $\mathrm{Sm} 42$ & SV & & & HM537084 \\
\hline $\operatorname{Sm} 43$ & SV & & & HM537085 \\
\hline Sm44 & SV & & & HM537086 \\
\hline Sm45 & SV & & & HM537087 \\
\hline Sm46 & SV & & & HM537088 \\
\hline $\operatorname{Sm} 47$ & SV & & & HM537089 \\
\hline $\operatorname{Sm} 48$ & SV & & & HM537090 \\
\hline Sm49 & SV & & & HM537091 \\
\hline $\operatorname{Sm} 50$ & SV & & & HM537092 \\
\hline
\end{tabular}

Locations where haplotypes were found: DV = McMurdo Dry Valleys (Taylor, Wright, and Victoria valleys and vicinity), SV = Southern Dry Valleys (Garwood, Marshall, and Miers valleys and vicinity), $\mathrm{BI}=$ Beaufort Island; $\mathrm{RI}=$ Ross Island, and $\mathrm{GH}=$ Granite Harbour.

To compound the subtle inter and intra-specific morphological variation in Antarctic Stereotydeus spp., several recent studies have found high levels of intra-specific 
mtDNA (COI) variation in otherwise morphologically similar populations of S. mollis (Stevens \& Hogg 2006, McGaughran et al. 2008). Pairwise COI sequence divergences of up to $17.5 \%$ have been reported between individuals of $S$. mollis from the McMurdo Dry Valleys in southern Victoria Land suggesting the possibility of cryptic species (Stevens \& Hogg 2006, McGaughran et al. 2008). A preliminary phylogenetic analysis of Stereotydeus spp. by Stevens \& Hogg (2006) using a 504 base pair (bp) portion of the COI gene found that $S$. mollis from the McMurdo Dry Valleys formed a polyphyletic group with $S$. shoupi from near the Beardmore Glacier. However, since their preliminary study, several more COI haplotypes of $S$. mollis have been identified which may improve the phylogenetic resolution among Stereotydeus spp. from Victoria Land and the Transantarctic Mountains.

Here, we more fully examine the geographic distributions and phylogenetic relationships among Stereotydeus spp. from Victoria Land and the Transantarctic Mountains using an analysis of all known COI sequences for $S$. mollis, $S$. belli and S. shoupi. To assess the phylogenetic affinities of Stereotydeus from Darwin Glacier we include new sequence data from the Darwin and Beardmore Glacier regions as well as from the southernmost Dry Valleys (Garwood, Marshall and Miers).

\section{Material and methods}

Sample collection

This study includes 39 previously published unique mtDNA COI haplotypes for Stereotydeus mollis collected from southern Victoria Land and deposited in GenBank (Stevens \& Hogg 2006, GenBank accession numbers DQ305385-87, DQ305389-98, DQ309572-74; McGaughran et al. 2008, GenBank accession numbers DQ305361-65, DQ30567, DQ30569-84) (Table I). In addition, 12 previously unpublished $S$. mollis COI haplotypes were identified from specimens collected from the southern Dry Valleys (Garwood, Marshall and Miers) in January 2009 (Fig. 1). Due to the differing haplotype nomenclature used in previous studies, and to aid in interpretation, these data were consolidated and a more simplified nomenclature assigned. Haplotypes were aligned and renamed using the generic prefix "Sm" followed by a unique numerical character (i.e. Sm1-Sm50). Table I lists all of the unique $S$. mollis haplotypes used in this study and cross references them with those identified by both Stevens \& Hogg (2006) and McGaughran et al. (2008).

Sequence data for $S$. shoupi from the central Transantarctic Mountains and for $S$. belli from northern Victoria Land were obtained from GenBank. (Stevens \& Hogg 2006, GenBank accession numbers DQ309576 and DQ309577, respectively). In addition, mites were collected from the Darwin Glacier region (Diamond Hill) in December 2004 and January 2007 as well as from the Beardmore Glacier region (Ebony Ridge) in January 2010. All individuals were morphologically identified as S. shoupi using Strandtmann (1967). Six individuals of $S$. shoupi were sequenced from Darwin Glacier and one from Beardmore Glacier.

\section{mtDNA extraction, amplification and sequencing}

Total genomic DNA was extracted from individual animals using the SIGMA REDExtract-N-Amp ${ }^{\mathrm{TM}}$ Tissue PCR Kit. Due to the small size of individual animals $(0.5-0.75 \mathrm{~mm})$, the manufacturer's recommended volume of extraction buffer was reduced by $90 \%$ to concentrate the resulting DNA extract. Following extraction, a $675 \mathrm{bp}$ fragment of the mitochondrial cytochrome $c$ oxidase (COI) gene was amplified using the mite specific primers COI-2R and COI-2F (Otto \& Wilson 2001). PCR amplification was carried out in a $20 \mu \mathrm{l}$ reaction containing $4 \mu \mathrm{l}$ of extracted DNA (unquantified), $1.0 \mu \mathrm{M}$ of each primer and $10 \mu l$ of $i$-Taq ${ }^{\mathrm{TM}}$ 2X PCR master mix (iNtRON Biotechnology, Gyeonggi-do, Korea). Thermocycling conditions were: initial denaturation at $94^{\circ} \mathrm{C}$ for $1.5 \mathrm{~min}$ followed by 40 cycles of denaturation and polymerase amplification $\left(94^{\circ} \mathrm{C}\right.$ for $20 \mathrm{~s}, 55^{\circ} \mathrm{C}$ for $30 \mathrm{~s}$ and then $1.5 \mathrm{~min}$ at $72^{\circ} \mathrm{C}$ ), followed by $5 \mathrm{~min}$ at $68^{\circ} \mathrm{C}$ (McGaughran et al. 2008).

All PCR products were purified using SAP/EXO (USB Corp, Cleveland, OH, USA). Sequencing using both forward and reverse primers was performed directly on a capillary electrophoresis ABI 3130XL genetic analyser (Applied Biosystems Inc, Foster City, CA) at the University of Waikato DNA sequencing facility.

\section{Phylogenetic analyses}

Individual sequences were confirmed as being derived from applicable taxa using the GenBank BLAST algorithm. A $504 \mathrm{bp}$ (168 codons) portion of unambiguous alignment (no insertions or deletions) of the COI gene was used to match the existing dataset as reported by Stevens \& Hogg (2006) and McGaughran et al. (2008). All sequences were aligned using Geneious Pro v4.7.6 (Drummond et al. 2009), and PAUP* ver.4.0b10 (Swofford 2002) was used to perform neighbour joining (NJ) analysis. Distance matrices of pairwise nucleotide sequence divergences were calculated in PAUP* using all unique sequences. Due to the number of sequences $(n=58)$ and available computing power, the Genetic Algorithm for Rapid Likelihood Inference as implemented in the computer program GARLI ver.0.951 (Zwickl 2006) was used for Maximum Likelihood analysis (ML). Several runs were performed in GARLI in order to obtain the corresponding ML tree of best fit (Zwickl 2006). The prostigmatid mite Eriorhynchus sp. (GenBank accession number AF142135; Otto \& Wilson 2001) was used as an outgroup as it was the most closely related taxon available on GenBank (Stevens \& Hogg 2006). $\chi^{2}$ tests as employed in PAUP* were used to determine whether the assumption of equal base frequencies among sequences was violated on all sites and third codon positions only. jModeltest 


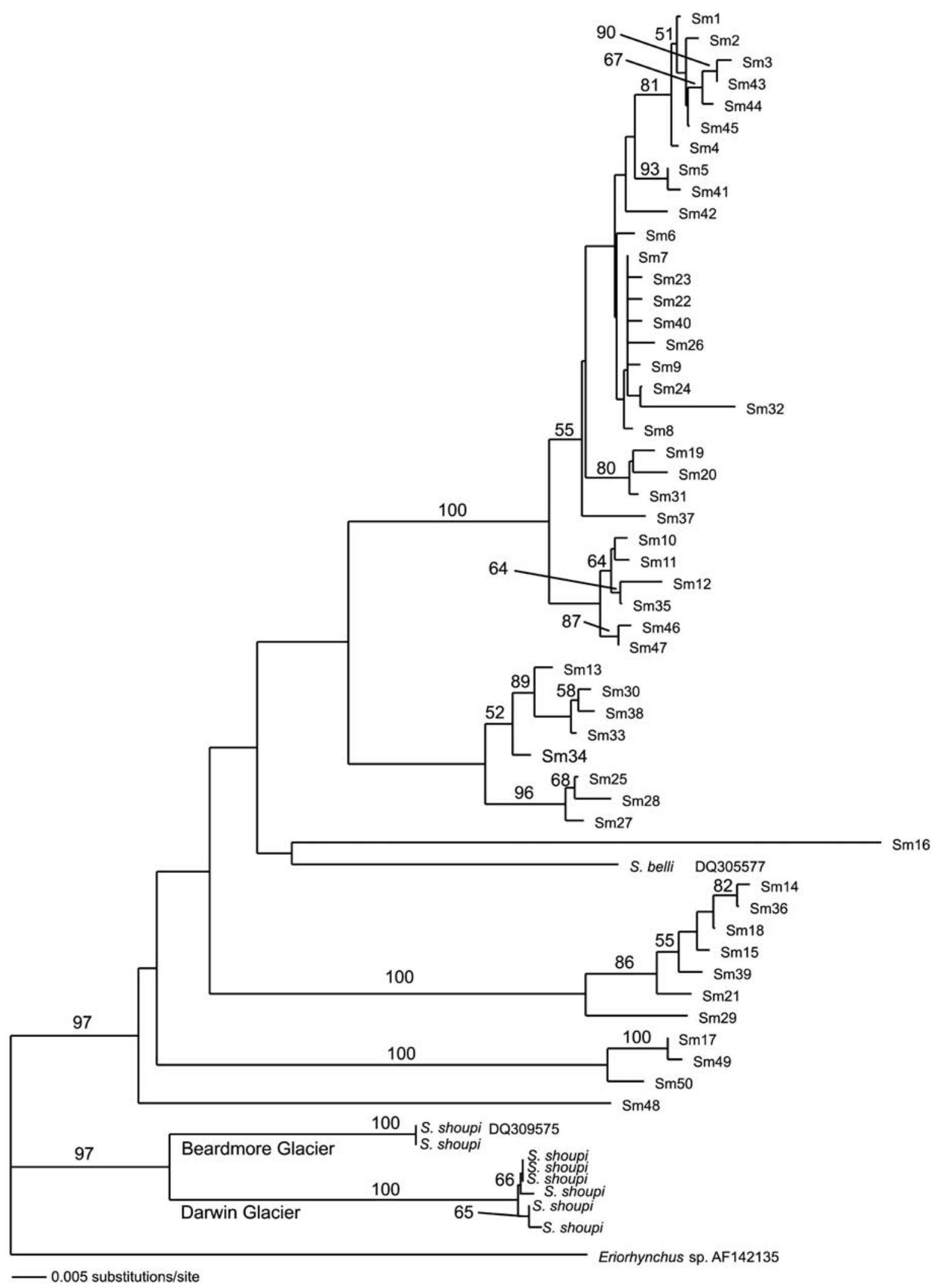

Fig. 2. Neighbour joining phylogram based upon all available Stereotydeus sequences from Victoria Land and the central Transantarctic Mountains using a 504 bp fragment of the mtDNA COI gene. Bootstrap confidence limits (1024 replicates) shown above nodes. Haplotype codes refer to those provided in Table I. 


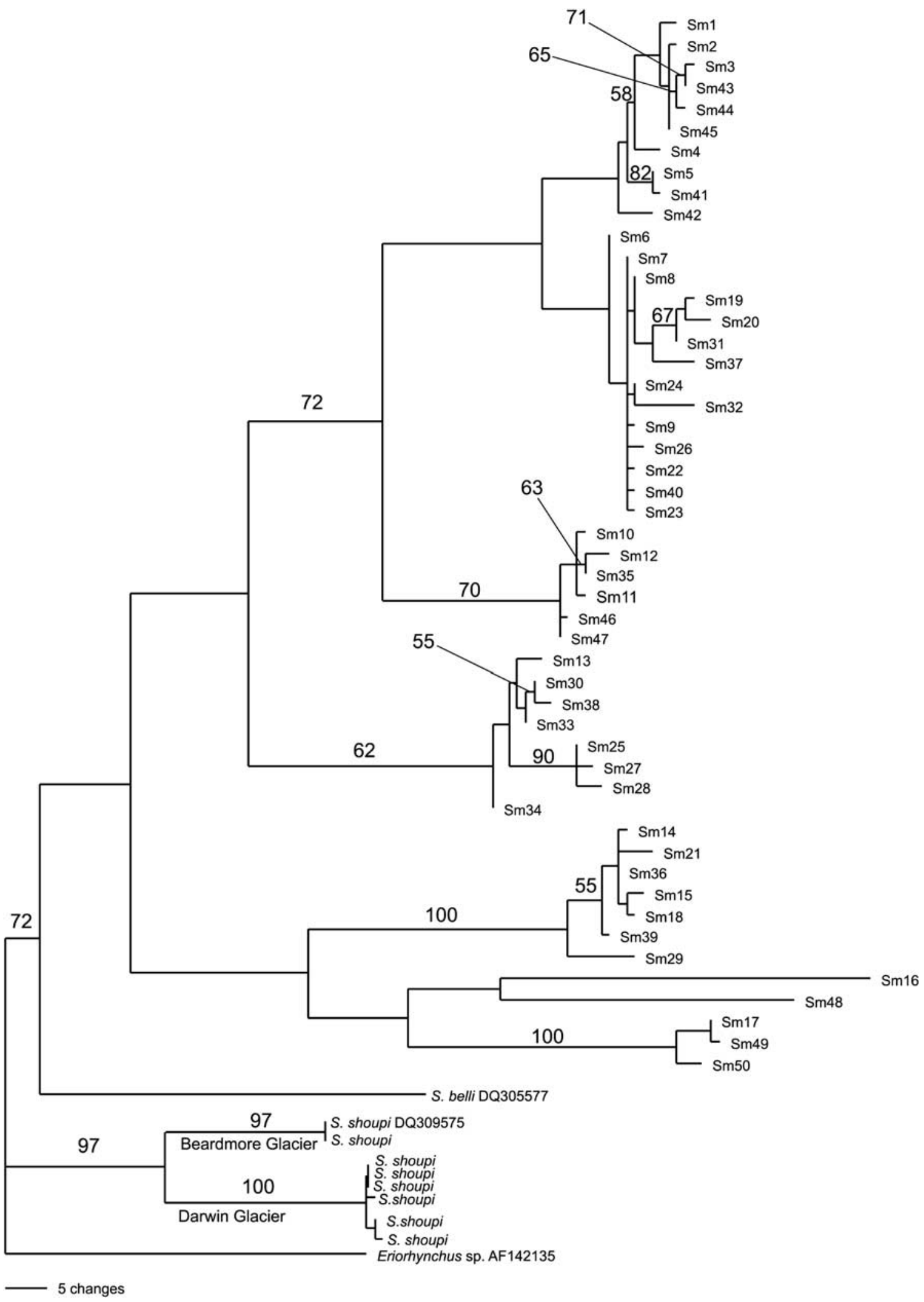

Fig. 3. Maximum likelihood phylogram based upon the substitution model HKY $+I+\Gamma(-\operatorname{lnL}=3158.0623(\mathrm{AIC})$; $\mathrm{Ti} / \mathrm{tv}$ ratio $=2.8729$ $I=0.5320 \Gamma=0.7250$ : with base frequencies set to $A=0.4094 C=0.0919 G=0.1180 T=0.3807)$ derived from $\mathrm{jModeltest}$ (see methods), using a $504 \mathrm{bp}$ fragment of the mtDNA (COI) gene from all available Stereotydeus sequences from Victoria Land and the central Transantarctic Mountains. Haplotype codes refer to those provided in Table I. 
(Guindon \& Gascuel 2003, Posada 2008) was used to select the appropriate substitution model of evolution for maximum likelihood (ML) heuristic searches (using all unique sequences). The ML model selected was $\mathrm{HKY}+I+\Gamma$ $(-\operatorname{lnL}=3158.0623$ (AIC); $\mathrm{Ti} / \mathrm{tv}$ ratio $=2.8729 I=0.5320$ $\Gamma=0.7250$ : with base frequencies set to $A=0.4094$ $C=0.0919 G=0.1180 T=0.3807$ ). All other options in GARLI remained as default. Bootstrap replicates $(n=1024)$ were performed to assess support for the phylogenies estimated by both NJ and ML analyses.

\section{Results}

mtDNA COI sequence variability

We found 11 unique $S$. mollis COI haplotypes from the southern McMurdo Dry Valleys resulting in a total of 50 haplotypes when combined with previously published data. Four haplotypes were obtained from the six $S$. shoupi collected from near the Darwin Glacier and a single haplotype from the S. shoupi collected from the Beardmore Glacier region. The nucleotide composition averaged over all sequences showed an A-T bias of $69.0-71.0 \%$ for all species $(A=35.8 \%, T=33.2 \%, C=16.1 \%, G=14.9 \%$ for S. mollis; $\mathrm{A}=35.7 \%, \mathrm{~T}=35.5 \%, \mathrm{C}=16.1 \%, \mathrm{G}=12.9 \%$ for S. shoupi; $\mathrm{A}=35.9 \%, \mathrm{~T}=34.8 \%, \mathrm{C}=15.8 \%, \mathrm{G}=13.5 \%$ for $S$. shoupi from the Darwin Glacier; and $\mathrm{A}=35.3 \%$, $\mathrm{T}=34.1 \%, \mathrm{C}=15.7 \%, \mathrm{G}=14.9 \%$ for $S$. belli). Base frequencies were homogenous among all sites $\left(\chi^{2}=20.6141\right.$, $p=1.00, \mathrm{df}=168$ ), and for third codon positions (168 sites, $\left.\mathrm{A}-\mathrm{T}=82.02 \% ; \chi^{2}=21.451, p=1.00, \mathrm{df}=168\right)$, across all taxa.

Among all the Stereotydeus sequences there were 326/ 178 constant/variable sites. Sequence divergence for the $50 \mathrm{~S}$. mollis haplotypes ranged from $0.2-17.5 \%$ (uncorrected pair wise distances). The six $S$. shoupi sequences from the Darwin Glacier $\left(79.5^{\circ} \mathrm{S}\right)$ were $0.2-0.6 \%$ divergent from each other and were $8.5-8.7 \%$ divergent from the two identical S. shoupi sequences from the Beardmore Glacier $\left(83.5^{\circ} \mathrm{S}\right)$. Stereotydeus shoupi were $13.7-18.1 \%$ divergent relative to S. mollis. The single S. belli sequence from Cape Hallett $\left(71^{\circ} \mathrm{S}\right)$ was $13.3-14.5 \%$ divergent from S. shoupi and 9.1-14.1\% divergent in comparison to $S$. mollis.

Sequence divergences (up to $17.5 \%$ ) within S. mollis, resulted in 37 amino acid differences at 25 variable sites. A single amino acid difference separated individuals of $S$. shoupi from the Beardmore and Darwin Glacier regions. There were 10 amino acid differences at nine variable sites for $S$. shoupi relative to $S$. mollis and 14 differences at 13 sites for $S$. shoupi relative to $S$. belli. There was also a single amino acid difference between $S$. belli and the most common amino acid sequences for $S$. mollis.

\section{Phylogenetic analyses}

Both the NJ and ML trees were similar and placed 48 of the $50 \mathrm{~S}$. mollis haplotypes into five divergent clades with bootstrap support $\geq 50 \%$. There was extremely strong bootstrap support in both the NJ and ML analyses for the placement of $S$. shoupi as basal to all other Stereotydeus analysed. In addition, both NJ and ML consistently grouped the four individuals of $S$. shoupi collected from near the Darwin Glacier with $S$. shoupi collected from near the Beardmore Glacier; $\geq 97 \%$ bootstrap support (Figs $2 \& 3$ ). For both the NJ and ML analyses, there was considerable disagreement in the placement of the highly divergent (up to $17.5 \%$ ) $S$. mollis haplotype $\mathrm{Sm} 48$ and the single available $S$. belli sequence. NJ analysis placed both $S$. belli and the $S$. mollis haplotype Sm16 within a highly divergent clade with low bootstrap support $(<50 \%)$ and $\mathrm{Sm} 48$ as basal to all other $S$. mollis haplotypes with very strong bootstrap support (97\%) (Fig. 2). In contrast, the ML analysis grouped Sm48 and Sm16 together into a similar, highly divergent clade with low bootstrap support $(<50 \%)$ while placing $S$. belli as basal to all $S$. mollis haplotypes (bootstrap support 72\%) (Fig. 3).

\section{Discussion}

The $504 \mathrm{bp}$ portion of the COI gene from the 50 known haplotypes of $S$. mollis used in this study showed very high levels of intra specific divergence (up to $17.5 \%$ uncorrected- $p$ distance). These levels of divergence exceeded the levels of inter-specific divergence found between the three recognized Stereotydeus species of southern Victoria Land suggesting that there may be cryptic species within S. mollis. Similar levels of COI divergence were found in morphologically identical specimens of the "pan-Antarctic" springtail Friesea grisea (Schäffer) from opposite sides of the continent and Torricelli et al. (2009) concluded that this was due to the presence of cryptic species.

Both NJ and ML analyses revealed five well-supported $S$. mollis clades and two discrete $S$. shoupi clades which grouped the sequences from Beardmore Glacier with the four $S$. shoupi sequences from Darwin Glacier. However, both NJ and ML analyses disagreed on the placement of both $S$. belli and the highly divergent $S$. mollis haplotype Sm48. This is possibly an artefact of using only a single $S$. belli sequence in the analyses rather than the choice of the COI gene for estimating species level phylogenies (Linares et al. 2009). For example, the inclusion of additional $S$. mollis and S. shoupi sequences, along with the four individuals of $S$. shoupi from the Darwin Glacier, increased the resolution of the phylogeny by placing $S$. shoupi as a monophyletic sister taxa with strong bootstrap support basal to all $S$. mollis haplotypes. This is in contrast to the position of $S$. shoupi as a clade within $S$. mollis as reported by Stevens \& Hogg (2006) using a more limited dataset.

The mtDNA COI gene has been widely accepted as a suitable molecular marker for the phylogenetic study of mite taxa and for investigating both the intra-specific relationships of populations at the species level as well as 
the inter-specific relationships of closely related species (Navajas \& Fenton 2002, Cruickshank 2002, Dabert 2006). Boyer et al. (2007), found a similar pattern of extremely high COI variability (up to $19.2 \%$ uncorrected- $p$ distance) in the arachnid Aoraki denticulata denticulata (Forster) endemic to the South Island of New Zealand. The inclusion of several sequences from the subspecies $A$. denticulata major (Forster), as well as other closely related sister taxa within the genus Aoraki, resulted in a deep branching phylogeny which was well supported by bootstrap analysis and suggested the presence of several cryptic species. These results were in agreement with previous research which has found increased resolution of phylogenies with the inclusion of a representative range of molecular data from closely related taxa (Talavera \& Castresana 2007).

Springtails and mites show broadly similar biogeographical patterns along the Victoria Land latitudinal gradient (Frati et al. 2000, 2001, Stevens \& Hogg 2006, McGaughran et al. 2010), although intraspecific and conspecific mite distances are greater in comparison with Collembola. The greater divergence values for mites, compared with springtails, may be due to mites' smaller size, higher activity levels and shorter generation time (Martin \& Palumbi 1993). The comparative hardiness of mites (Sjursen \& Sinclair 2002), may also have allowed them to survive in additional refugia during past glaciations, resulting in the complex patterns of genetic diversity that we see today. Differences in the eco-physiological behaviour of G. hodgsoni observed by McGaughran et al. (2009), if present in Stereotydeus, could also contribute to increased genetic divergence rates and possibly correlate with the deeper branches within our mite phylogeny.

Based on the COI sequence data, we conclude that the range of $S$. shoupi extends northward towards the Darwin Glacier and that $S$. shoupi is a monophyletic sister taxon of $S$. mollis. The availability of only a single $S$. belli COI sequence severely limited the ability to accurately place it within the phylogeny as evidenced by the low bootstrap support values and differing placements within the NJ and ML trees. The addition of further $S$. belli sequences, from across its distributional range, may help resolve its relationship with that of the highly divergent lineages of $S$. mollis. Sequence data from other Stereotydeus sp. from across the Antarctic continent hold the promise of a more comprehensive understanding of the evolutionary history of Antarctic Stereotydeus.

\section{Acknowledgements}

We thank Antarctica New Zealand (AntNZ), and the United States Antarctic Program (USAP) for logistical support enabling sample collection. The New Zealand Foundation for Research, Science and Technology (FRST), the National Science Foundation (NSF), the University of Waikato Vice Chancellor's Fund, and the Department of Biological Sciences, University of Waikato provided financial support. N. Demetras was supported by a New Zealand Terrestrial Antarctic Biocomplexity Survey (NZTABS) graduate scholarship from the University of Waikato as well as a SCAR International Fellowship award. Thanks to D. Wall and U. Nielson for their help collecting near the Beardmore Glacier and to the Sierra Nevada Brewing Co. for their generous donation of field apparel. This paper contributes to the SCAR Evolution and Biodiversity in the Antarctic (EBA) programme and Antarctica New Zealand's Latitudinal Gradient Project (LGP), Key Question 2 (The role of large-scale ice structures).

\section{References}

Boyer, S.L., Baker, J.M. \& Gonzalo, G. 2007. Deep genetic divergences in Aoraki denticulata (Arachnida, Opiliones, Cyphophthalmi): a widespread 'mite harvestman' defies DNA taxonomy. Molecular Ecology, 16, 4999-5016.

Caruso, T. \& Bargagli, R. 2007. Assessing abundance and diversity patterns of microarthropod assemblages in northern Victoria Land (Antarctica). Polar Biology, 30, 895-902.

Cruickshank, R.H. 2002. Molecular markers for the phylogenetics of mites and ticks. Experimental \& Applied Acarology, 7, 3-14.

DABERT, M. 2006. DNA markers in the phylogenetics of Acari. Biological Letters, 43, 97-107.

Drummond, A.J., Ashton, B., Cheung, M., Heled, J., Kearse, M., Moir, R., Stones-Havas, S., Thierer, T. \& Wilson, A. 2009. Geneious, ver.4.6, Available from http://www.geneious.com/.

Frati, F., Spinsati, G. \& Dallai, R. 2001. Genetic variation of mtCOII gene sequences in the collembolan Isotoma klovstadi from Victoria Land, Antarctica: evidence for population differentiation. Polar Biology, 24, 934-940.

Frati, F., Fanciulli, P.P., Carapelli, A., Dell'ampio, E., Nardi, F., Spinsati, G. \& Dallai, R. 2000. DNA sequence analysis to study the evolution of Antarctic Collembola. Italian Journal of Zoology, 1, 133-139.

Fittkau, E.J., Illies, J., Kilinge, H., Schwabe, G.H. \& Sioli, H. 1969. Biogeography and ecology in South America. Berlion: Springer, 516 pp.

Gressitt, J.L., Fearon, C.E. \& Rennell, K. 1964. Antarctic mite populations and negative arthropod surveys. Pacific Insects, 6, 531-540.

Gressitt, J.L., Leech, R.E. \& Wise, K.A.J. 1963. Entomological investigations in Antarctica. Pacific Insects Monograph, 5, 287-304.

Guindon, S. \& Gascuel, O. 2003. A simple, fast, and accurate algorithm to estimate large phylogenies by maximum likelihood. Systematic Biology, 52, 696-704.

Linares, M.C., Soto-Calderón, I.D., Lees, D.C. \& Anthony, N.M. 2009. High mitochondrial diversity in geographically widespread butterflies of Madagascar: a test of the DNA barcoding approach. Molecular Phylogenetics and Evolution, 50, 485-495.

Marshall, D.A. \& Pugh, P.J.A. 1996. Origins of the inland Acari of continental Antarctica, with particular reference to Dronning Maud Land. Zoological Journal of the Linnean Society, 118, 101-118.

Martin, A.P. \& PAlumbi, S.R. 1993. Body size, metabolic rate, generation time, and the molecular clock. Proceedings of the National Academy of Science of the United States, 90, 4087-4091.

McGaughran, A., Hogg, I.D. \& Stevens, M.I. 2008. Patterns of population genetic structure for springtails and mites in southern Victoria Land, Antarctica. Molecular Phylogenetics and Evolution, 46, 606-618.

McGaughran, A., Redding, G.P., Stevens, M.I. \& Convey, P. 2009. Temporal metabolic rate variation in a continental Antarctic springtail. Journal of Insect Physiology, 55, 130-155. 
McGaughran, A., Torricelli, G., Carapelli, A., Frati, F., Stevens, M.I., Convey, P. \& Hogg, I.D. 2010. Contrasting phylogeographical patterns for springtails reflect different evolutionary histories between the Antarctic Peninsula and continental Antarctica. Journal of Biogeography, 37, 103-119.

Navajas, M. \& Fenton, B. 2002. The application of molecular markers in the study of diversity in Acarology: a review. Experimental and Applied Acarology, 24, 751-774.

Olivier, P.A.S. 2006. A first record of the family Penthalodidae Thor, 1932 (Acari: Prostigmata) from South African soils, with descriptions of two new species in the genus Stereotydeus Berlese, 1901. African Entomology, 14, 53-622.

Otто, J.C. \& Wilson, K.J. 2001. Assessment of the usefulness of ribosomal $18 \mathrm{~S}$ and mitochondrial COI sequences in Prostigmata phylogeny. In Halliday, R.B., Walter, D.E., Proctor, H.C., Norton, R.A. \& Colloff, M.J., eds. Acarology: Proceedings of the 10th International Congress. Melbourne: CSIRO Publications, 100-109.

PosaDA, D. 2008. jModelTest: Phylogenetic model averaging. Molecular Biology and Evolution, 25, 1253-1256.

PitTARD, D.A. 1971. A comparative study of the life stages of the mite Stereotydeus mollis W. \& S. (Acarina). Pacific Insects Monograph, 25, $1-14$.

SJuRsen, H. \& Sinclair, B.J. 2002. On the cold hardiness of Stereotydeus mollis (Acari: Prostigmata) from Ross Island, Antarctica. Pedobiologia, 2, 188-195.

Spain, A.V. 1971. Some aspects of soil conditions and arthropod distribution in Antarctica. Pacific Insects Monograph, 25, 21-26.
Spain, A.V. \& Luxton, M. 1971. Catalogue and bibliography of the Acari of the New Zealand subregion. Pacific Insects Monographs, 25, $177-226$.

Stevens, M.I. \& Hogg, I.D. 2006. Contrasting levels of mitochondrial DNA variability between mites (Penthalodidae) and springtails (Hypogastruridae) from the Trans-Antarctic Mountains suggests long-term effects of glaciation and life history on substitution rates, and speciation processes. Soil Biology and Biochemistry, 38, 3171-3180.

Strandtmann, R.W. 1967. Terrestrial Prostigmata (Trombidiform Mites). Antarctic Research Series, 10, 51-80.

Swofford, D.L. 2002. PAUP*. Phylogenetic Analysis Using Parsimony ( ${ }^{*}$ and other methods), ver. 4. Sunderland, MA: Sinauer Associates.

Talavera, G. \& Castresana, J. 2007. Improvement of phylogenies after removing divergent and ambiguously aligned blocks from protein sequence alignments. Systematic Biology, 56, 564-577.

Torricelli, G., Carapelli, A., Convey, P., Nardi, F., Boore, J.L. \& Frati, F. 2009. High divergence across the whole mitochondrial genome in the "pan-Antarctic" springtail Friesea grisea; evidence for cryptic species? Gene, 449, 30-40.

Womersley, H. \& Strandtmann, R.W. 1963. On some free living prostigmatic mites of Antarctica. Pacific Insects, 5, 451-472.

ZwICKL, D.J. 2006. Genetic algorithm approaches for the phylogenetic analysis of large biological sequence datasets under the maximum likelihood criterion. $\mathrm{PhD}$ thesis, The University of Texas at Austin, 125 pp. [Unpublished]. 